\title{
Connection of fertilization conditions of sour cherry and meteorological parameters
}

\author{
Lakatos, L. ${ }^{1}$, Szabó, T. ${ }^{2}$, Soltész, M. ${ }^{4}$, Szabó, Z. ${ }^{4}$, Dussi, M.C. ${ }^{3}$ \& Nyéki, J. ${ }^{4}$ \\ ${ }^{1}$ University of Debrecen, Centre for Agricultural Sciences and Engenering, Hungary \\ ${ }^{2}$ Fruit Research and Extension Institute of Úffehértó, Hungary \\ ${ }^{3}$ Fucultad de Ciencias Agrarias, Universidad Nacional del Comahue \\ ${ }^{4}$ University of Debrecen, Institute for Research and Development, Hungary
}

\begin{abstract}
Summary: Our analyses showed that the degree of free fertilization is mostly influenced by maximum temperature and sunshine duration. We found that free fertilization ratio increases with higher daily maximum temperatures; similar results characterise sunshine duration as well, namely we observed higher free fertilization ratio at higher sunshine duration values. Total amount of precipitation during the period between blossoming and maturity and the difference between the average daytime and night temperatures have an important role in the tendency of maturity time. Photosynthesis and respiration are essentially significant in the development of biological systems. These two processes are mostly regulated by the daytime and night temperatures. Therefore, it is not surprising that if the difference between daytime and night temperatures is large, it means intensive photosynthesis and a low degree of respiratory loss. Under these conditions intensive development and ripening can take place; however, in case of a low temperature difference intensive respiration slows down the process of development. Duration of ripening is also significantly influenced by the amount of precipitation of the period between blossoming and maturity. Abundant precipitation slows down the process of ripening, while dry weather accelerates it. Self-fertilization takes place in a space isolated from the environment. In spite of that, we found that effectiveness of self-pollination significantly depends on the meteorological conditions. Degree of self-fertilization is influenced directly by temperature and indirectly by other climatic parameters. We found a significant connection between the values of maximum and minimum temperatures during blossoming and the ratio of self-fertilization. Increase of maximum temperature reduces the effectiveness of self-pollination. A $1{ }^{\circ} \mathrm{C}$ increase of maximum temperature reduces self-fertilization ratio by $0,6 \%$. In the case of minimum temperature we can state that the morning minimum temperature of $7,5-8,5^{\circ} \mathrm{C}$ is the most favourable. If minimum temperatures are under $4{ }^{\circ} \mathrm{C}$ or above $12{ }^{\circ} \mathrm{C}$, self-fertilization ratio reduces to the quarter of the value characteristic at $8{ }^{\circ} \mathrm{C}$. We believe that the effectiveness of self-fertilization can be improved considerably by the rational placement of isolator bags within the crown area, avoiding their placement to the external, western crown surface.
\end{abstract}

Key words: fertilization, minimum-maximum temperature, night and day temperature

\section{Introduction}

Free fertilization shows a very close dependence on weather. We can generally state that rainy, cool weather is not favourable for pollination. In case of free fertilization the blossoms of the trees can be pollinated by pollen coming from the surrounding trees. Fertilization of the 'Pándy' sour cherry blossoms which were pollinated at different times was observed by Pejkic (1966). He found that the percentage of fruit set was the largest on the first day after pollination and it significantly decreased later. There was no fruit set at all 72 hours after pollination. If pollination and fertilization do not take place within 48 hours after the opening of the blossoms, the embryo sack and the ovule degenerate, fruit set does not happen. Pollination has to take place at the time of blossom opening or not later than the next day in order for the fertilization to be satisfactory. Vitality of ovules lasts a particularly short time in the case of 'Pándy' sour cherry blossoms.
According to Nyéki (1989) degree of joint blossoming of self-sterile varieties has to be above $70 \%$ for a secure pollination. In case of 'Pándy' sour cherry this joint blossoming level is even larger, at least $80 \%$. The joint blossoming level above $70 \%$ can be assured in most years by varieties belonging to the same blossoming groups, if the varieties are classified into 3 (early, medium, late) blossoming groups. The joint blossoming of two varieties is not adequate if its value is under $50 \%$; these variety combinations can not be planted together (Nyéki, 1974). The joint blossoming level providing satisfactory pollen supply and secure pollination can only be achieved by the joint plantation of more (2-4) pollen providing varieties. Joint blossoming was close (74\%) with the 'Cigánymeggy 7' type and it was not satisfactory (48\%) with the 'Germersdorfi óriás 57 ' sour cherry variety. Mostly, varieties are classified into three blossoming groups. Brózik és Nyéki (in Nyéki, 1980) set up four blossoming groups. Creation of five blossoming groups is recommended in countries with 
extreme weather. Maliga (1953) created eight blossoming groups while simultaneously investigating cherry and sour cherry varieties. Blossoming of the self-sterile 'Pándy'sour cherry was stated as medium by Stancevic (1969) and medium-late by Blasse (1964) and Kellerhals (1986).

Since self-fertilization takes place in isolator bags, certain meteorological parameters have fewer roles in the tendency of self-fertilization. We can state, that sunshine duration and amount of precipitation have no direct effect on self-pollination. Certainly, these factors have indirect effects, because sunshine duration influences the thermal conditions of the given day. In case of sunny weather we can usually expect higher daytime maximum temperatures, but morning minimums are lower with a clear sky. The role of rainy days is also mostly significant because of the change of temperature. Rainy days are chillier and show smaller thermal amplitude than clear, cloudless ones. Moisture content of the air may also show differences within the isolator compared to the outside conditions. However this has only a small influence on the effectiveness of pollination. Sour cherry can be classified into the medium early blossoming species, it blossoms the latest among stone fruits (Soltész, 2000). Nyéki (1989) compared the starting time of blossoming of 26 varieties at 4 locations. He observed 2 weeks of difference in the starting time of blossoming.

Wocior (1976) concluded that in the case of varieties blossoming early the first blossoms set fruits at a lower degree; while in the case of varieties blossoming later blossoms opening by the main blossoming time did so. Medium blossoming varieties had the smallest difference among the fruit set of blossoms opening at different times. In the case of varieties with the latest blossoming, the lowest fruit set was observed at blossoms that opened the latest. Pollination of sour cherry has to take place within 40 ours after the opening of the blossoms for a satisfactory fruit set.

\section{Materials and methods}

The varieties analysed at the Research Station in Újfehértó are kept under completely identical production area and growth circumstances (growth area, crown shape, phyto- and agro-technology, plant protection). The analytical samples have been and are collected from random block sample plots approved and registered by the National Institute for Agricultural Quality Control.

We typified meteorological situations as follows: we distinguished warm, chilly, clear and cloudy, dim weather situations. The bases of categorization were the average values of the previous years and the standard deviation values for the given day. If the value concerning the given day (sunshine duration, temperature) was higher than the multiple year average plus the value of the deviation than we considered that day warm and clear.

If the value concerning the given day was lower than the multiple year average minus the value of the deviation than we considered that day cloudy and chilly.
The statistical analysis was carried with the SPSS 13.0 for Windows software package. We determined regressions, frequencies, deviations. The graphs of the functions were made with Excel spreadsheet software.

\section{Degree of free fertilization}

In the case of the observed varieties free fertilization occurred between 5-45\% during the period between 1983 and 2008. 'Újfehértói fürtös' showed the best fertilization ratios 'Debreceni bőtermő' was the second best fertilizing variety followed by the 'Kántorjánosi' sour cherry variety (Figure 1). Analysing the frequency distribution function we can conclude that 'Újfehértói fürtös' approximates normal distribution the most, in the case of 'Debreceni bötermo"', and 'Kántorjánosi' varieties we experience a significant decline at the $20-25 \%$ fertilization ratio. Lower and higher fertilization ratios represent a significantly higher frequency within the sample. This fact indicates that we can expect equalized yield mostly in the case of the 'Újfehértói fürtös' variety.

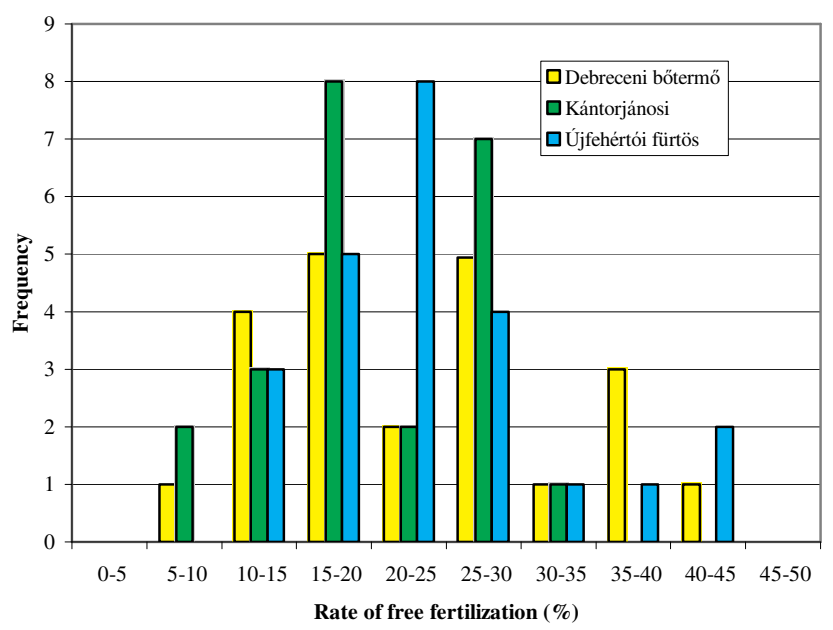

Figure 1: Distribution of free fertilization at reaserched sour cherry cultivars

Degree of free fertilization is influenced by the tendency of maximum temperature. At higher temperatures degree of free fertilization is higher, while at a daily maximum temperature of $15^{\circ} \mathrm{C}$ it is around $12-15 \%$, at a maximum temperature of $25^{\circ} \mathrm{C}$ we can expect a free fertilization ration between $25 \%$ and $30 \%$. According to our results we can conclude that $1^{\circ} \mathrm{C}$ of maximum temperature increase improves the degree of free fertilization by $1,5-2 \%$ (Figure 2 ).

Beside temperature sunshine duration also influences the degree of free fertilization. According to our measurement results we can state that as a result of increasing sunshine duration, degree of free fertilization has improved. Sunny weather is a favourable condition for the pollinating activity of insects. As Figure 3 shows, in case of a sunshine duration of $60-70$ hours a free fertilization of $10-15 \%$ characterizes the observed sour cherry varieties. At a sunshine duration of 120-130 hours free fertilization reaches 25-30\%. Every 10 our increase of sunshine duration during blossoming improves the degree of free fertilization by $2,5 \%$. 


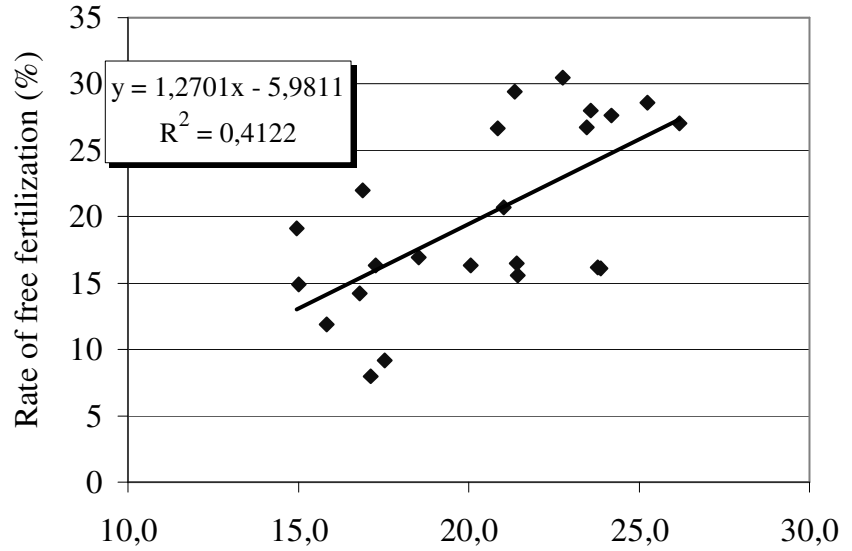

Maximum temperature $\left({ }^{\circ} \mathrm{C}\right)$

Figure 2: Relationship between free fertilization and average maximum temperature of blooming period at "Újfehértó fürtös" sour cherry cultivar (Újfehértó, 1983-2008)

If we analyse hydrical parameters beside thermal variables we can conclude the following: Amount of precipitation during blossoming usually has an unfavourable influence on the degree of free fertilization. This means that in case of increasing amount of precipitation fertilization ratio decreases. At $60-70 \mathrm{~mm}$ of total precipitation an $8-12 \%$ fruit set is usual, while at $0-10 \mathrm{~mm}$ of total precipitation free fertilization is between 25-30\% (Figure 4). In rainy weather insects are unable to fly and because of the wet and humid air, pollination by wind can be realized on a small degree only.

If we analyse the tendency of fruit set during the period between 1983 and 2008 we can conclude the following: We experienced the worst fruit set in the year of 2001, while the best fruit set took place in 1989. According to Table 1, better fruit set occurred when blossoming took place at an earlier date and lasted a short time only. Temperatures were significantly higher in the year with the best fruit set compared to the ones of the year with the worst fruit set. This is true for minimum, maximum and average temperatures as well. In relation with hydrical parameters we can conclude, that the total precipitation of the best fruit set year does not even reach the tenth of the precipitation during the worst fruit set year. Number of rainy days in the best fruit set year was less then one-third than in the case of the worst fruit set year.

Tables 1. Some phenological and meteorological parameters of worst and best fruit set years at free fertilization case

\begin{tabular}{|l|c|c|}
\hline \multicolumn{1}{|c|}{ Year } & Worst fruit set & Best fruit set \\
\hline $\begin{array}{l}\text { Start of bloom from January } \mathbf{1} \\
\text { (day) }\end{array}$ & 1998 & 2005 \\
\hline Length of bloom (day) & 110 & 109 \\
\hline Minimum temperature $\left({ }^{\circ} \mathbf{C}\right)$ & 9 & 14 \\
\hline Average temperature $\left({ }^{\circ} \mathbf{C}\right)$ & 4,0 & 6,7 \\
\hline Maximum temperature $\left({ }^{\circ} \mathbf{C}\right)$ & 13,3 & 10,9 \\
\hline Amount of precipitation $(\mathbf{m m})$ & 25,0 & 15,0 \\
\hline Number of rainy days (day) & 1,3 & 67,3 \\
\hline Sunshine duration (hour) & 3 & 9 \\
\hline
\end{tabular}

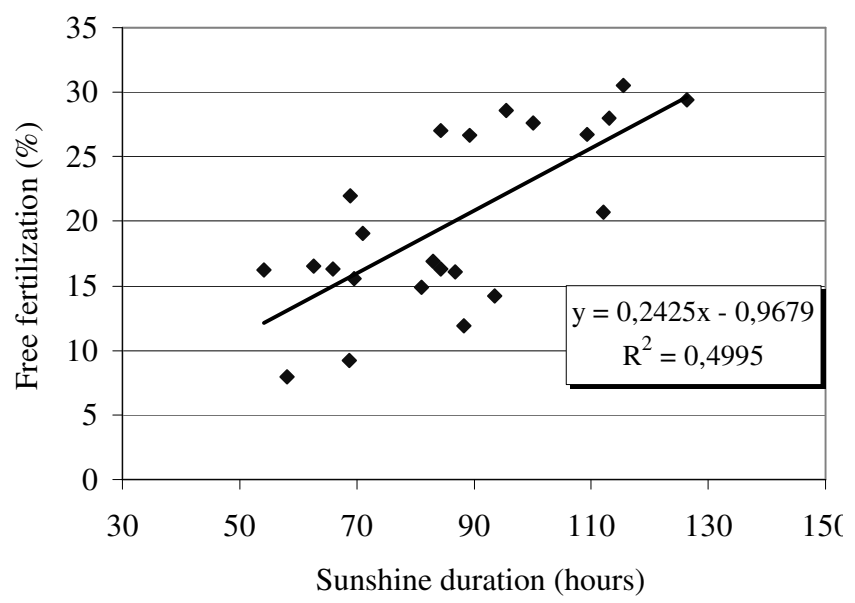

Figure 3: Relationship between free fertilization and amount of sunshine duration during the blooming period at "Újfehértó fürtös" sour cherry cultivar (Újfehértó, 1983-2008)

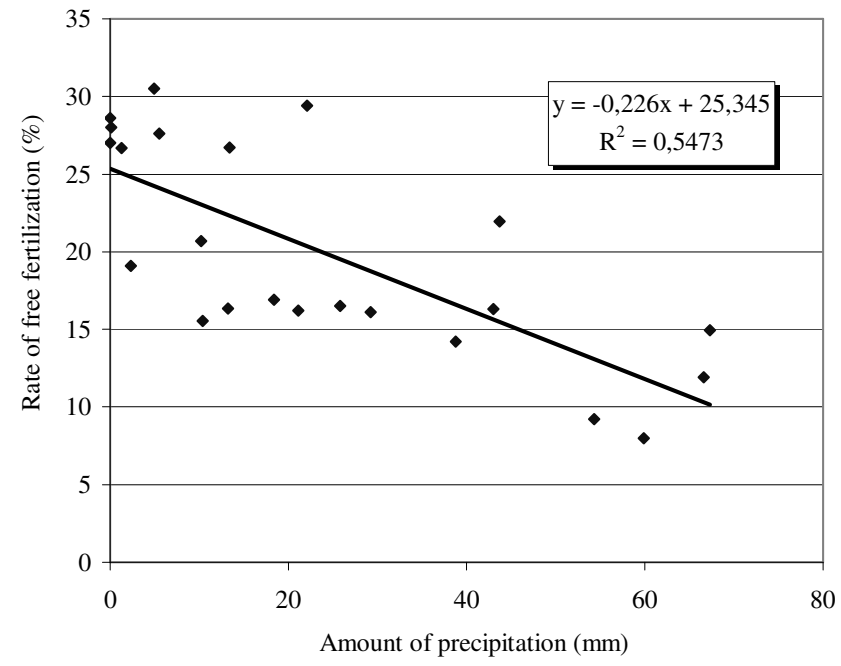

Figure 4: Relationship between free fertilization and amount of precipitation during the blooming period at "Kántorjánosi" sour cherry cultivar (Újfehértó, 1983-2008)

We can also state, that during the best fruit set years there were twice as high sunshine duration values during blossoming than in the worst fruit set year.

\section{Degree of self-fertilization}

Self-fertilization ratio was between $2,5-22,5 \%$ in the case of the observed sour cherry varieties during the period between 1983 and 2008. Among the three sour cherry varieties observed by us 'Debreceni bőtermő' provided the best self-fertilization ratio, which is followed by 'Újfehértói fürtös' and then 'Kántorjánosi'. We do not find considerable difference among the varieties, distribution functions consecutively follow normal distribution slightly distorted to the left (Figure 5).

Analytical results showed that maximum temperature during blossoming has a significant connection with the degree of self-fertilization. In case of increasing maximum temperatures, self-fertilization ratio decreases. We believe 


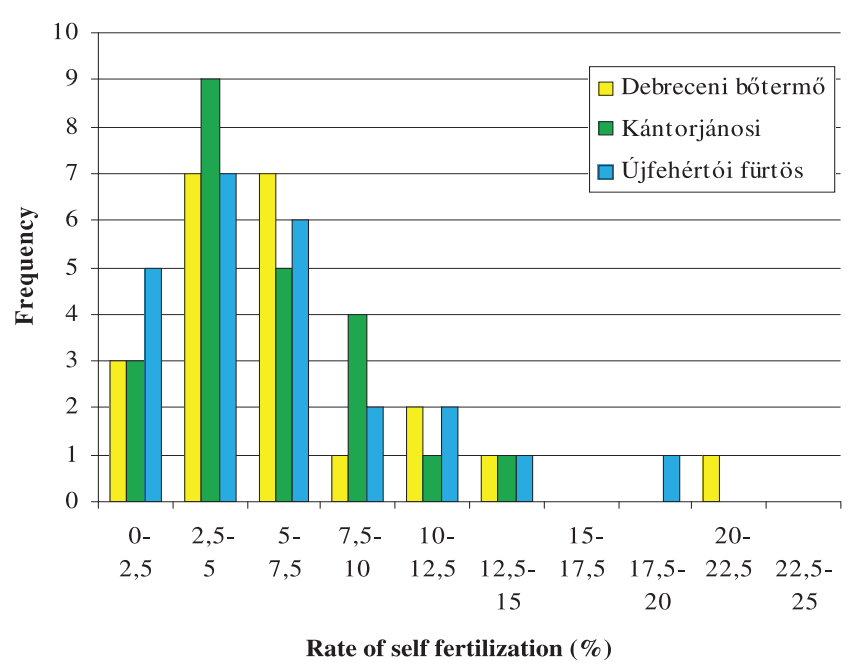

Figure 5: Distribution of self fertilization at researched sour cherry cultivars

that it is due to fact that very high temperature within the isolator bags has an adverse effect on fertilization processes. The lack of air motion and the overheating because of the closed space are unfavourable conditions. If the daily maximum temperature reaches $25^{\circ} \mathrm{C}$, self-fertilization ratio is $2-4 \%$. However, in case of a $15^{\circ} \mathrm{C}$ daily maximum temperature we can expect an $8-10 \%$ self-fertilization ratio (Figure 6). Therefore we can conclude that every $1^{\circ} \mathrm{C}$ of maximum temperature increase reduces the degree of selffertilization by $0,6 \%$. Therefore it is of great significance which pole of the crown we place the isolator bags. Although the white bags have high albedo values and only slightly heat up by direct sunlight, they should not be exposed to the effects of direct solar radiation for a long time. Selffertilization effectiveness of isolator bags placed to the northern and eastern sides might be 2-3\% better than of the ones placed into the southern and western parts of the crown.

Besides maximum temperatures also the minimum temperature conditions of the stand showed a close connection with the degree of self-fertilization. We can state that neither very low nor very high minimum temperatures are favourable for self-fertilization. The second-degree polynomial describing the connection indicates that the highest values of self-fertilization ratio occurred at a minimum temperature between $8^{\circ} \mathrm{C}$ and $9^{\circ} \mathrm{C}$. If morning minimum temperature is above $12^{\circ} \mathrm{C}$ or below $3^{\circ} \mathrm{C}$, selffertilization ration is only $2-3 \%$ (Figure 7). Morning minimum temperatures can be reduced by means of a cooling irrigation, so temperature values above $9^{\circ} \mathrm{C}$ can be kept on an optimal level. There is also a possibility to increase temperatures; by means of gas-burners we can increase the morning temperatures of stand areas even by multiple ${ }^{\circ} \mathrm{C}$.

Analysing the fruit set tendency of blossoms under isolator bags during the period between 1983 and 2008 we can conclude the following: We experienced the worst fruit set in 1998, while the best fruit set was in 2005. According to Table 2 we might notice that better fruit set occurred when blossoming lasted longer, maximum temperatures did not exceed $15{ }^{\circ} \mathrm{C}$ and there was an abundant, $60 \mathrm{~mm}$

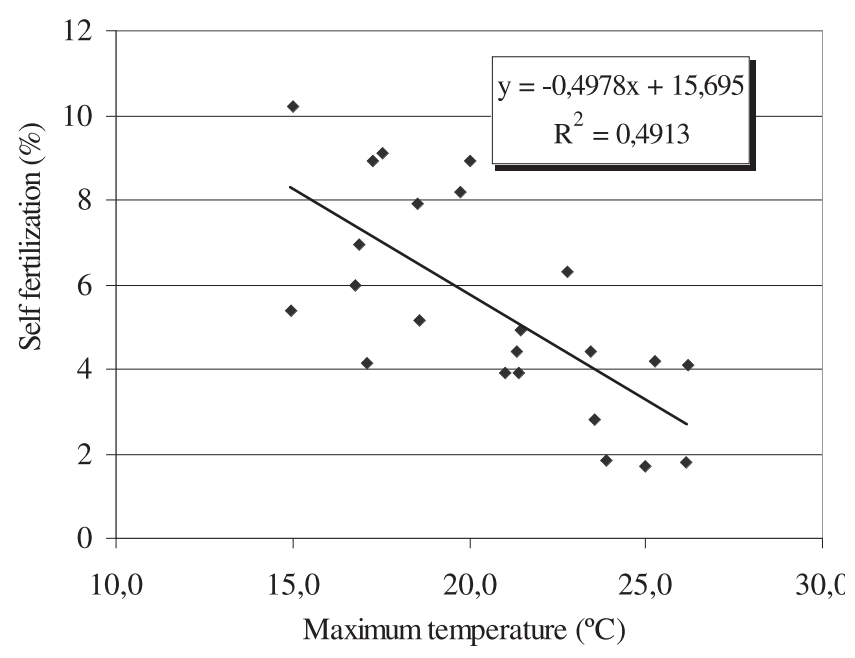

Figure 6: Relationship between self fertilization and maximum temperature of blooming period at "Kántorjánosi" sour cherry cultivar (Újfehértó, 1983-2008)

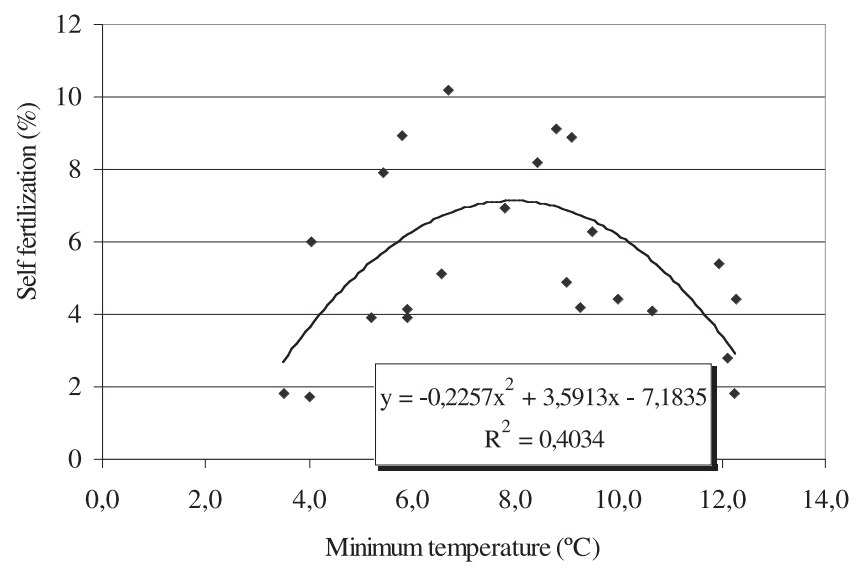

Figure 7: Relationship between self fertilization and average of minimum temperature during the blooming period at "Debreceni bőtermö" sour cherry cultivar (Újfehértó, 1983-2008)

precipitation during blossoming. These conditions are expressly unfavourable in view of free fertilization, but in the case of self-fertilization they are considered advantages. Since self-fertilization does not require either insect activity or wind, defense against overheating is more effective on rainy, dim days than in the case of clear, dry weather.

\section{Conclusions}

Microclimate of the stand has very important role in the tendency of both free and self-fertilization. Not only the crown area of the stand is a special radiation interceptor surface, but there are major thermal and humidity differences at the different poles of the crown area. Since isolator bags are usually not placed within the internal space of the crown area, exposure presents itself more intensively within them. If we track the tendency of the meteorological conditions of the stand area, we will have the opportunity to modify it by means of the application of irrigation systems with properly formed 
upper sprinklers. We believe that the effectiveness of selffertilization can be improved considerably by the rational placement of isolator bags within the crown area, avoiding their placement to the external, western crown surface.

\section{References}

Blasse, W. (1964): Phaenologische und befruchtungsbiologischzytologische Untersuchungen an Sauerkirschen. Achir für Gartenbau., 2: 147-158.

Brózik, S. \& Nyéki, J. (1980): A meggy. (In: Nyéki J. (szerk.): Gyümölcsfajták virágzásbiológiája és termékenyülése) Mezőgazdasági Kiadó Budapest, 205-234

Kellerhals, M. (1986): Die befruchtungsver halfnisse der obstdorten. (Schuluss). Schweiz. Zeitschrift für Obst- und Weinbau 122 (13): 363-371.

Maliga, P. (1953): Meggyfajták termékenyülési vizsgálatainak eredményei. MTA. Agrártud. Oszt. Közl., 3 (1-2): 177-215.

Nyéki, J. (1974a): Meggyfajták virágzása és termékenyülése. Kandidátusi értekezés. MTA, Budapest (kézirat).
Nyéki, J. (1974b): Meggyfajták termékenyülése. Kert. Egy. Közl., 38: 147-159.

Nyéki, J. (1989): Csonthéjas gyümölcsűek virágzása és termékenyülése. MTA Doktori értekezés, Budapest (kézirat).

Nyujtó, F. (1958): Pándy meggy. Meggy termékenyülési vizsgálatok. A Duna-Tisza közi Mezögazd. Kis. Int. évi jelentése, 153-154.

Nyujtó, F. (1966): Termeszthető-e gazdaságosan a meggy? Az FM. és a Kert. és Szölészet Tud. Tanácsadója. Csonthéjasok, 5-9.

Ritiu, C. (1975-76): Contributii la studiul fertilitatii principalelor sciuri devisin din tara noastra. Lucrari Stiintifice, 18-19. (197): 109-112. p.

Soltész, M. (2000): Gyümölcsfajok virágzási sorrendje. „Lippay János-Ormos Imre -Vas Károly” Tudományos Ülésszak. Budapest. Összefoglalók, Kertészettudomány, 288-289.

Stancevic, A. S. (1969): The investigation of blooming period, time of maturity and productivity of sour cherry cultivars. J. Yugos. Pomol., 9: 1-15.

Wocior, S. (1976): Badania nad Wybranymi zapodnieniami biologii Kwitniwntia i owocowania wisni. II. Badania samoplodnosci i potencjalnej plodnosti wisni. Rozn. Nauk. Roln., 101 (3): 7-16. 